\title{
Benthic soft-bodied algae as bioindicators of stream water quality
}

\author{
R. Stancheva ${ }^{\star}$ and R.G. Sheath
}

Department of Biological Sciences, California State University San Marcos, San Marcos, 333 S. Twin Oaks Valley Rd., California 92096-0001, USA

\author{
Received December 13, 2015 - Revised January 21, 2016 - Accepted January 25, 2016
}

\begin{abstract}
This review presents the state-of-the-art of benthic soft-bodied algae as biondicators of stream and river water quality, with emphasis on bioassessments set by the legislation (e.g., European Water Framework Directive, USA Clean Water Act) to promote the restoration and ensure ecological sustainability of water resources. The advantages and shortcomings of a variety of bioassessment field and laboratory methods for algae are discussed. The increasing use of soft-bodied algae in biotic indices to assess individual anthropogenic stressors, and in multimetric indices of biotic integrity to evaluate ecological condition in streams is summarized. Rapid microscopic and molecular approaches for inferring nutrient supply with heterocystous cyanobacteria and other sensitive algae are proposed. The need of better understanding of soft-bodied algae as bioindicators is discussed and suggestions are made for obtaining meaningful bioassessment information with cost-efficient efforts.
\end{abstract}

Key-words: Bioassessment / water quality / benthic soft-bodied algae / stream / river

Résumé - Les algues benthiques à corps mou comme bioindicateurs de la qualité de l'eau en rivière. Cette revue présente l'état de l'art des algues benthiques à corps mou comme bioindicateurs de la qualité de l'eau en rivière, avec un accent sur l'évaluation biologique fixée par la législation (par exemple, la directive européenne cadre sur l'eau, le Clean Water Act USA) pour promouvoir la restauration et assurer la durabilité écologique des ressources en eau. Les avantages et les inconvénients de diverses méthodes de bioévaluation de terrain et de laboratoire pour les algues sont discutés. L'utilisation croissante des algues à corps mou dans les indices biotiques pour évaluer les facteurs de stress anthropiques, et les indices multimétriques d'intégrité biotique pour évaluer l'état écologique des cours d'eau est présentée. Les approches rapides microscopiques et moléculaires avec des cyanobactéries hétérocystées et d'autres algues sensibles pour déduire l'apport de nutriments sont proposées. La nécessité d'une meilleure compréhension des algues à corps mou comme bioindicateurs est discutée et des suggestions sont faites pour obtenir de bonnes données de bioévaluation d'un bon rapport coût-efficacité.

Mots-clés : évaluation biologique / qualité de l'eau / algues benthiques à corps mou / courant / rivière

\section{Introduction}

In streams, benthic algae are one of the most species-rich organism groups (Meyer, 2007) and the rationale for their use in bioassessments has been summarized in previous reviews (see Whitton and Kelly, 1995; Lowe and Pan, 1996; Stevenson and Smol, 2003; Stevenson, 2014). The most important advantages of benthic algae over other stream organisms as bioindicators are outlined as follows: (a) benthic algae are sessile, or have limited movement, and they cannot avoid potential pollution through migration or other means, and thus they must either tolerate the ambient environment or perish; (b) the generation time ranges from a few days for unicellular organisms to several months for larger multicellular, filamentous and colonial soft-bodied algae (belonging to all non-diatom algal taxonomic groups, including cyanobacteria) and thus short- and long-term shifts in environmental conditions can be observed (Jarlman, 1996; Whitton, 2012); (c) algae have

\footnotetext{
* Corresponding author: rhristov@csusm.edu
}

species-specific environmental tolerances and preferences and directly respond to water chemistry (such as nutrient levels, salinity, $\mathrm{pH}$, organic pollution, herbicides, etc.); (d) benthic algal communities are typically species-rich and spatially compact, so a few square centimeters of substratum may support over a hundred species, each one with specific environmental requirements, and thus represents an information-rich system for environmental monitoring (modified from Lowe and Pan, 1996). Compared to macroinvertebrates and fish, algae are better suited for local-scale or upstream-downstream studies and better indicate water chemistry and land use that alters water quality, because of their position at the base of food webs and restricted motility (Johnson, 2006; Resh, 2008). Due to their desiccation tolerance, algae could be the only water quality bioindicator in intermittent streams in more arid areas.

Ecological indicators, which are measurable structural or functional characteristics of the ecosystems, including biological conditions (USEPA, 2002) are central to bioassessment, with their primary role being to evaluate ecosystem responses 
to anthropogenic stress (i.e., deviation from ecological integrity, Niemi and McDonald, 2004). Algae are bioindicators of both structural components of ecological integrity (taxonomic composition) and functional integrity (biomass, rates, pattern and relative importance of processes) (Dolédec and Statzner, 2010). The water-quality criteria in countries around the world are established by legislation and large-scale bioassessment projects are designed to evaluate the stream health and to support water resource management decisions. The goal of the USA Clean Water Act (CWA, 1972) is to restore and maintain the physical, chemical, and biological integrity of water resources and to have surface waters with biological integrity, defined as "the capability to support and maintain a balanced, integrated, adaptive community of organisms having species composition, diversity, and functional organization comparable to that of natural habitat of the region" (Frey, 1977). Biological condition is usually measured in terms of deviation from a natural or minimally disturbed condition, and reference conditions for biological integrity refers to the "naturalness" of the structure and function of the biota in the absence of significant human disturbance or alteration (Stoddard et al., 2006). Similar water-quality governmental policies and guidance are developed in Australia and New Zealand (ANZECC, 2000). Recent European Union (EU) legislation instituted the Water Framework Directive (WFD, EC, 2000) in which key components are a general requirement for ecological protection and a sustainable water use that is applicable to all surface waters - rivers and streams among others. The WFD requires all surface water bodies to achieve "good ecological status" by 2015 , defined as having a biota consistent with only slight alterations from that expected in the absence of human impact (reference conditions). This goal is similar to the concept for biological integrity in the US (Stevenson et al., 2010). Each member state in the European Union has had to establish methods for assessing ecological status for a range of biological quality elements, one of which is "macrophytes and phytobenthos".

Despite the equal treatment of diatoms and soft-bodied (i.e. non-diatom) algae in the "saprobic system" of Kolkwitz and Marsson (1908), diatoms have received increasing attention in the past century due to their easy use as bioindicators (reviewed by Stevenson et al., 2010; Whitton, 2013). The current state-of-art in algae-based river and stream bioassessment in the EU shows that the diatoms are developed and intercalibrated as proxies for phytobenthos, gradually narrowed to an application of a few diatom indices (Poikane, 2015). The softbodied algae supplement either phytobentos or macrophyte stream assessment systems in several states, and the abundance of the phytobentos is not evaluated (Kelly, 2013; Poikane, 2015). The only exception is Norway, whose stream bioassessment is based completely on soft-bodied algae (Schneider and Lindstrøm, 2009, 2011). The US national bioassessments are largely based on diatom community composition, supplemented by total algal biomass data and proportional abundance of all algal taxonomic groups. Ecological integrity and ecological status are holistic concepts not confined to any single taxonomic group and require understanding of both the state of a particular indicator group and its interaction with other organisms and the catchment (Kelly, 2013). In theory, information gained from the entire benthic algal community can provide a more comprehensive indication of environmental conditions (Kelly, 2006). The broader understanding of the conditions of the benthic algal communities is important especially in situations where different pressures have resulted in shifts in the balance between algal taxonomic groups (Kelly, 2013).

The merit of soft-bodied algae as bioindicators has been noted by researchers which conducted small, usually singlewatershed bioassessment studies worldwide, for instance in Spain (Fernandez-Piñas et al., 1991; Douterelo et al., 2004), Russia (Rusanov et al., 2012); Canada (Vis et al., 1998), Brazil (Rodrigues and Bicudo, 2001), Argentina (Loez and Topalián, 1997), New Zealand (Winterbourn, 1990). In Asia, many countries need capacity building programs to develop aquatic bioassessment techniques commonly used in Europe, US, Japan and South Korea (Goulden, 2011). Currently, softbodied algae metrics (Hill et al., 2000, Griffith et al., 2002; Porter et al., 2008; Danielson et al., 2011; Potapova and Carlisle, 2011) and indices based solely on soft-bodied algae (Gutowski et al., 2004; Schaumburg et al., 2004; Schneider and Lindstrøm, 2009, 2011; Fetscher et al., 2014) have been developed for large-scale stream bioassessments in Europe and the US.

However, surprisingly little has been published addressing the performance of diatoms compared to soft-bodied algae as bioindicators (Lavoie et al., 2004; Kelly, 2006, Kelly et al., 2008, Schneider et al., 2012, 2013; Stancheva et al., 2013b) or on the relative strength of indices derived from a single assemblage vs. combined assemblages (Potapova and Carlisle, 2011; Fetscher et al., 2014). Some of these studies (e.g., Lavoie et al., 2004; Kelly et al., 2008; Potapova and Carlisle, 2011) contribute to the impression that soft-bodied algae did not improve stressor responsiveness of diatoms alone, but they were based on taxonomy methods that allowed mainly genus-level or coarser identifications of soft-bodied algae which may account for the conclusions. In contrast, studies designed to explore the full potential of soft-bodied algae demonstrated that they enhance bioassessment power along the following lines of consideration: (1) multimetric indices based on entire algal communities, created in southern Californian streams, showed better responsiveness to anthropogenic stress over indices based either on diatoms or soft-bodied algae assemblages alone (Fetscher et al., 2014); (2) the best performing softbodied algal index exhibited greater discriminatory power than its diatom counterpart near the higher end of the range of anthropogenic disturbance (Fetscher et al., 2014); (3) differences in diatom and soft-bodied algal biotic indices were detected in ecosystems which are subject to changing environmental conditions; these differences could provide indications related to ecosystem stability (Schneider et al., 2012); (4) diatom and soft-bodied algal communities respond to nutrient supply and $\mathrm{pH}$ differently, with diatom taxon richness generally increasing with nutrient availability in contrast to decreasing soft-bodied algae richness (Schneider et al., 2013); (5) diatoms in conjunction with soft-bodied algae provide a more robust assessment of nutrient conditions, inferring nitrogen $(\mathrm{N})$ limitation in $20 \%$ more sites than monitoring with either algal group alone (Stancheva et al., 2013b). 
While the diatom analytical bioassessment methods are focused on species composition and the data are easy to calibrate, large variability exists among the soft-bodied algae methodologies which target different parameters of algal community. The goal of this review was to compare the currently applied analytical methods for soft-bodied algae in large-scale bioassessments, to discuss their cons and pros, efforts level, and resulting contribution/input to stream water quality evaluation. Better understanding of the value of soft-bodied algae as bioindicators and the appropriate methods for their analysis according to the bioassessment goal can help an informed decision-making for water quality management. In addition, algal-nutrient interactions are discussed in the light of their bioindicator potential. Examples are included from our research experience incorporating soft-bodied algae in stream bioassessment in California as part of the Surface Water Ambient Monitoring Program of the California State Water Resources Control Board (SWAMP, http://www.waterboards.ca.gov/water_ issues/programs/swamp/) (Stancheva et al., 2012a,b, 2013a,b, 2014, 2015; Fetscher et al., 2013-2015; Wehr et al., 2013).

\section{Field and laboratory bioassessment methods for soft-bodied algae}

The less frequent use of soft-bodied algae in bioassessment relative to diatoms is likely due in part to challenges associated with soft-algal species-level identification and quantification of specimens, which have contributed to the impression that they are less measurable and not cost-effective (Lavoie et al., 2004). The major obstacle for soft-bodied algae evaluation consists in their naturally broad variation of thallus size and associated morphological diversity of vegetative and reproductive structures, which are taxonomically fundamental. For practical reasons, soft-bodied algae are often separated based on their size to macroalgae and microalgae (Sheath and Cole, 1992), requiring different methodological treatment either during the sample collection, or during the subsequent sample processing and species identification.

The second hurdle is the stream heterogeneity (Palmer and Poff, 1997) and patchy distribution of macroalgae in streams (Sheath and Cole, 1992), which may cause bias for algal collection if quantitative random sampling is employed. Luce et al. (2010) showed that the highest benthic algal biomass is accumulated in a transition refuge zone away from the thalweg across bed-rock rivers due to geomorphic factors. Many long-living macroalgae, such as Chara, Cladophora, Batrachospermum, Lemanea, Stigeoclonium reflect water chemistry over long periods of time and are important indicators of highly variable nutrient levels (Whitton, 2012). However, the macroalgae differ in their preferences to stream physical habitat conditions. Consequently, several sampling approaches are used to overcome the heterogeneity of benthic soft-bodied algae distribution and to improve the macroalgal detection. Larger macroalgae, such as Lemanea, Chara, Cladophora, and Vaucheria, are included in macrophyte bioassessment surveys of WFD (Kelly, 2013). For habitats with great spatial and temporal variation, qualitative targeted sampling of algae is highly recommended option to the random quantitative sampling in the US national surveys (Stevenson and Smol, 2003). Fresh qualitative samples with stream macroalgae are collected additionally to the quantitative sampling in California (Fetscher et al., 2009), capturing many indicator macroalgae species (Table 1). Similar to the variety of sampling techniques, numerous corresponding laboratory methods for algae exists. Selecting the appropriate methodology for collecting and laboratory processing of benthic soft-algae is a crucial first step for obtaining reliable data and meaningful bioassessment results.

In this section we will discuss the methodology for standardized large-scale bioassessment programs, which survey the general patterns of algal composition and biomass temporally and spatially. Such data can be used for water resource assessments in discussions of possible changes to water quality, land-use management regimes, or the classification of streams according to degree or type of anthropogenic impact.

\subsection{Field sampling of soft-bodied algae}

Sampling design and techniques vary with monitoring needs, study dataset scale, stream types, targeted habitats, factors affecting algae distribution and budget (see for details Stevenson and Smol, 2003; Lowe and Pan, 2006). Currently, there are two main soft-bodied algae sampling approaches used in large-scale stream bioassessment programs worldwide.

A semi-quantitative sampling approach for soft-bodied algae is employed in the EU. This method has been developed in Norway (Jarlman et al., 1996), but become a standard method in large-scale biomonitoring surveys of streams and rivers and as part of the European Project Standardization of River Classifications protocol (STAR, http://www. eu-star.at/frameset.htm) in Germany (Pipp and Rott, 1996) and Austria (Pfister and Pipp, 2013). The method had been designed to evaluate algal species composition and to provide semi-quantitative estimates of species abundance on a 5-point scale or directly as percent cover in the field. In summary, macroscopic algae are surveyed along a stream bottom of approximately $10 \mathrm{~m}$ using an aquascope to identify the percentage of the bottom surface covered by differently appearing algal elements, which are collected and stored separately in vials. Microscopic algae are brushed from an area of about $8 \times 8 \mathrm{~cm}$ on the upper side of each of ten stones, with diameters ranging between 10 and $20 \mathrm{~cm}$, taken from each sampling site according to Kelly et al. (1998). Semi-quantitative algal sampling allows for the separate collection of well-preserved algal thalli, which is important for species identification of macroalgae. Three to ten replicates are collected from each substratum sampled and data obtained with this method has been successfully used for indicator species optima calculations and development of algal indices (Rott et al., 1997, 1999; Schneider and Lindstrøm, 2009, 2011; Schneider et al., 2013; Rott and Schneider, 2014). Generally, the results obtained by this approach are comparable to diatoms, targeting the taxonomic composition and structure of soft-bodied algae communities. The main disadvantage of this method is the lack of algal biomass estimate, which may limit its application in harmful algal blooms monitoring and managing.

Quantitative algal sampling is preferred technique in the US bioassessment. Two quantitative sampling approaches 
Table 1. Macroalgal indicator species and non-reproducing "morphospecies", evaluated using indicator species analysis for stream bioassessment in California, which require qualitative sampling and large amount of material for species identification. Indicator classes are defined for total dissolved phosphorus (TP low $<10 \mu \mathrm{g} \cdot \mathrm{L}^{-1} \mathrm{high}>100 \mu \mathrm{g} \cdot \mathrm{L}^{-1}$ ), total dissolved nitrogen ( TN low $<0.2 \mathrm{mg} \cdot \mathrm{L}^{-1}$, high $>3 \mathrm{mg} \cdot \mathrm{L}^{-1}$ ), dissolved organic carbon (DOC low $<1.6 \mathrm{mg} \cdot \mathrm{L}^{-1}$, high $>8.3 \mathrm{mg} \cdot \mathrm{L}^{-1}$ ), dissolved copper $\left(\mathrm{Cu}\right.$ low $<0.3 \mu \mathrm{g} \cdot \mathrm{L}^{-1}$, high $>1.7 \mu \mathrm{g} \cdot \mathrm{L}^{-1}$ ) and "reference" conditions (algal taxa selected from Fetscher et al., 2014).

\begin{tabular}{|c|c|c|c|c|c|}
\hline \multirow[t]{2}{*}{ Taxon } & \multicolumn{5}{|c|}{ Indicator class } \\
\hline & $\mathrm{TP}$ & TN & $\mathrm{DOC}$ & $\mathrm{Cu}$ & "Reference" \\
\hline Calothrix fusca (Kütz.) Bornet and Flahault & & low & & & \\
\hline Calothrix parietina (Nägeli) Thuret & & & & & ref. \\
\hline Cladophora glomerata (L.) Kütz. & high & high & high & high & non-ref. \\
\hline Mougeotia calcarea (Cleve) Wittr. & low & & & & \\
\hline Mougeotia sp. 1 (d: 9-15 $\mu \mathrm{m})$ & low & & & & \\
\hline Mougeotia sp. 2 (d: 22-30 $\mu \mathrm{m})$ & low & & & & \\
\hline Mougeotia sp. 3 (d: 18-22 $\mu \mathrm{m})$ & low & & & & ref. \\
\hline Nostoc verrucosum Vaucher $e x$ Bornet and Flahault & low & low & & & ref. \\
\hline Nostochopsis lobatus H.C.Wood em. Geitler & low & & & & \\
\hline Oedogonium sp. 1 (d: 35-45 $\mu \mathrm{m})$ & & & high & & non-ref. \\
\hline Oedogonium sp. 3 (d: 10-16 $\mu \mathrm{m})$ & & & & & non-ref. \\
\hline Oedogonium sp. 5 (d: 4-6 بm) & & high & & & \\
\hline Paralemanea catenata (Kütz.) M. L.Vis and Sheath & low & & & & \\
\hline Rhizoclonium hieroglyphicum (C. Agardh) Kütz. & & high & high & high & non-ref. \\
\hline Rivularia minutula (Kütz.) Bornet et Flahault & low & & & & \\
\hline Sheathia involuta (Vis and Sheath) Salomaki and Vis & low & & & & \\
\hline Spirogyra borgeana Transeau & low & & & & \\
\hline Spirogyra majuscula Kütz. & low & & & & \\
\hline Spirogyra varians (Hassall) Kütz. & low & & & & \\
\hline Spirogyra weberi Kütz. & low & & & & \\
\hline Spirogyra sp. 1 (d: 33-40 $\mu \mathrm{m}$, plane w., 1 chl.) & low & & & & \\
\hline Spirogyra sp. 2 (d: 25-32 $\mu \mathrm{m}$, plane w., 1 chl.) & low & & & & \\
\hline Spirogyra sp. 4 (d: 60-105 $\mu \mathrm{m}$, plane w., 5-8 chl.) & high & & & & \\
\hline Spirogyra sp. 12 ( $d$ : 110-145 $\mu \mathrm{m}$, plane w., 5-8 chl.) & & & high & & \\
\hline Tolypothrix distorta Kütz. ex Bornet and Flahault & & & low & & ref. \\
\hline Ulothrix zonata (Weber and Mohr) Kütz. & & & low & & ref. \\
\hline Ulva flexuosa Wulfen & & & high & & non-ref. \\
\hline Zygnema sterile Transeau & low & & & & \\
\hline Zygnema sp. 1 (d: 26-31 um) & low & & & & \\
\hline
\end{tabular}

Abbreviations: d. - filament diameter, w. - transverse wall, chl. - chloroplast, ref. - "reference".

are applied in the US national stream bioassessments: (1) multihabitat sampling used by the Environmental Protection Agencys (USEPA) Environmental Monitoring and Assessment Program (EMAP, http://www.epa.gov/emap; protocols by Lazorchak et al., 1998, 2000; Stevenson and Bahls, 1999) and the National Rivers and Streams Assessment program (NRSA, http://water.epa.gov/type/rsl/ monitoring/riverssurvey/; USEPA, 2007 protocol); and (2) single targeted-habitat sampling used by the United States Geological Surveys (USGS) National Water-Quality Assessment Program (NAWQA; http://water.usgs.gov/nawqa, protocol by Acker, 2002; Moulton et al., 2002). Modification of the multihabitat quantitative sampling of algae is also adopted by the SWAMP program in California (Fetscher et al., 2009). Benthic soft-bodied algae are collected at 11 objectively selected locations spaced evenly across a $150 \mathrm{~m}$ or $250 \mathrm{~m}$ long stream reach (depending upon whether the average wetted width of the stream is less or greater than $10 \mathrm{~m}$ ). The sampling locations alternate between the points defined at 25\%, 50\% and $75 \%$ of the wetted width in high-gradient systems, and at "margin-center-margin" positions in low-gradient systems. Within each reach, samples are obtained from whatever substrata (e.g., cobble, silt/sand, gravel, bedrock, wood, concrete) are present at a single location across each of the 11 transects and combined into a well-mixed composite sample from which four aliquots are drawn for analysis of soft-bodied algae, diatoms, chlorophyll $a$ and ash-free dry mass (Fetscher et al., 2009). The total surface area sampled for each stream reach is recorded, and typically does not exceed $150 \mathrm{~cm}^{2}$. The modification of the method in California consists of collecting 
of additional qualitative fresh sample containing all visible macroalgae within the stream reach (Fetscher et al., 2009). This sample compensates the possible bias of the random quantitative algae sampling and allows for additional information, such as reproductive structure observation and molecular data collection.

Multihabitat quantitative sampling is a cost-effective method, which provides consistent and repeatable sampling of algae in conjunction with diatoms, macroinvertebrates and physical habitat (Hughes and Peck, 2008). A similar multihabitat sampling technique is employed in the stream biomonitoring in the New Zealand with consideration that it enables testing for statistical significance of differences among sites and for diagnosis of impacts (Biggs and Kilroy, 2000). According to Stevenson and Bahls (1999), this method best characterizes the benthic algae in the stream reach. However, our experience showed that the objectively selected sampling locations are not always representative for the entire algal diversity in the surveyed stream reach and many macroalgal taxa are recorded only qualitatively, possibly collected from the marginal transition refuge zones (Hughes and Peck, 2008; Luce et al., 2010).

The quantitative algal sampling may target a singlesampling habitat (Moulton et al., 2002). Algal samples are collected across five transects from richest targeted habitat where maximum taxa richness is likely to be observed along a 150 to $300 \mathrm{~m}$ stream reach. A single habitat type is sampled across all monitored streams for a comparability of results, as habitat selection is based on the following priority: (1) epilithic habitat - riffles in shallow streams with coarse-grained substrates; (2) epidendric habitat - woody snags in streams with fine-grained substrates; and (3) epiphytic habitat - macrophyte beds in streams where riffles and woody snags are absent. The sampled substratum area is recorded. Additional quantitative samples are collected from depositional-targeted habitats, and qualitative multihabitat algal samples are elective. Shorter lengths of stream reaches may be sampled for single habitat samples because the chosen single habitat (e.g., riffles) is usually common within the study streams (Stevenson and Bahls, 1999). Species composition of assemblages from a single microhabitat is expected to reflect water quality differences among streams more precisely than multihabitat sampling, but impacts in other habitats in the reach may be missed (Stevenson and Bahls, 1999). A modification of the single targeted-habitat method is implemented in algal bioassessment by the Ontario Ministry of the Environment (2011) and is preferred in small-scale studies when biomass of benthic algae is assessed (e.g., O'Brien and Wehr, 2010), or species composition associations with environmental variables is explored (Brown et al., 2008; Rusanov et al., 2012).

All quantitative sampling protocols include replicate sampling of a subset of $10 \%$ of sites in order to register the error variation associated with random sampling in large surveys as a measure of the precision of assessment at all sites.

\subsection{Taxonomic analysis and quantification of soft-bodied algae}

Once the preserved and fresh algal samples arrive in the laboratory, their analysis has two objectives. The first objec- tive is to adequately characterize the species composition of the algal community, which sets the scope for interpretation and evaluation in any resource or pollution monitoring investigation (Biggs and Kilroy, 2000). The second objective is to quantify the algal community, which is the basis of statistically valid data interpretation, calculation of diversity indices, optima and tolerances for indicator species (after ter Braak and van Dam, 1989; Dufrêne and Legendre, 1997), and algal biomass. Algal quantification can be either absolute, by obtaining species-specific cell densities or biovolumes, or based on relative abundance of taxa. The soft-bodied algal identification process, which requires detailed observation of all taxonomically relevant morphological features, might interfere with biovolume quantification of algal taxa and as a result, different taxonomic approaches exist with emphasis on either objective.

The European standard semi-quantitative method (Jarlman et al., 1996) is best suited for taxonomic identification of algae, but does not yield an estimate of algal biovolume within the stream reach. Macroalgae are identified from many separately collected samples and often fresh samples are available. Dissecting and compound light microscopes are used for sorting the material and species identifications are done in counting chambers or microscope slides. Percent cover for each macroalgal species measured in the field is converted to a 5-point scale or is used directly. Relative abundance of microalgae is estimated on the same scale from additionally collected samples, excluding diatoms.

In contrast, laboratory procedures which follow quantitative algal sampling in the US, prioritize the objective to precisely estimate the density or biovolume of benthic algae by counting algal cells in a known number of microscopic fields in a subsample of known volume (Stevenson and Bahls, 1999; Biggs and Kilroy, 2000; Acker, 2002). The composite algal sample is blended mechanically to break up large filaments and colonies, and the small mixed subsample is suspended in Palmer-Maloney counting chambers for species identification and biovolume estimates. A quantity of 300 algal "cell units" or "natural counting units", including the "living" diatoms with intact chloroplasts (Stevenson and Bahls, 1999; Biggs and Kilroy, 2000; Acker, 2002) are identified and counted. In this way, often more than $50 \%$ of the estimated total algal biovolume is attributed to living diatoms (Potapova and Charles, 2005), which limits soft-bodied algal analysis due to the low number of specimens observed. More current laboratory methods associated with multihabitat quantitative sampling improves the macroalgal treatment by its separate evaluation in Sedwick-Rafter chamber and extends microalgal counts to 300 soft-bodied algal entities, after initial blending of the sample (USEPA, 2008). According to Biggs (1987) and Biggs and Kilroy (2000), thorough sample blending minimizes subsampling error without damaging thalli. In contrast, we argue that this sample processing may lower the resolution of taxonomic analysis, especially in regards to macroalgal component characterized by high diversity of vegetative and reproductive morphology, which need to be observed during the identification process (review by Stancheva et al., 2012a). Simultaneous analysis of diatoms and soft-bodied algae provides valuable quantitative information for biovolume proportions among taxonomic groups, which is 
important in determination of potential shift in dominant algal groups. However, only diatoms are subject to further detailed taxonomic evaluation by specific methods (Stevenson and Bahls, 1999; Acker, 2002), while soft-bodied algae composition remains underinvestigated.

The best approach to obtain detailed taxonomic data for soft-bodied algal community from preserved quantitative composite samples is a separate processing of macroalgal and microalgal fractions, preferably by analyzing abundant macroalgal material, in conjunction with observing reproductive morphology from fresh samples. A novel quantification method for stream soft-bodied algae collected by multihabitat quantitative sampling for the SWAMP program in California was developed in an attempt to increase taxonomic resolution of the data and to produce precise biovolume information (Stancheva et al., 2012a, 2015). Sample blending is avoided by gentle removal of macroalgae, which preserves their integrity. Then macroalgae are processed separately in a gridded petri dish, and identified microscopically. Microalgae, excluding diatoms, are counted on microscope slides with a single layer of cells for a better observation of morphological features. Qualitative analysis of additional fresh samples is an important step for identifying macroalgae, because large amount of algal material is observed including reproductive structures. Fresh samples allow isolation, culturing and molecular studies on species of interest, such as taxonomically problematic genera (e.g., Zygnema and Spirogyra (Stancheva et al., 2012c, 2013a), rare, sensitive and potentially endemic species (Wehr et al., 2013), or nuisance algae and harmful cyanobacteria (Fetscher et al., 2015). This methodology, although time-consuming, enhances the power of water-quality assessments by better knowledge of local algal flora (Porter et al., 2008).

According to Stevenson et al. (1996), quantitative methods for algae estimate accurately assesses algal biomass and taxonomic shifts, but is time-consuming and may have high error variances. Quality assurance techniques register the error variance of laboratory sample processing and algae identification by requiring that $10 \%$ of the samples are counted by two taxonomists for large-scale bioassessment projects. Consistency in taxonomic identifications within a laboratory and in a program is very important and is maintained by development of online identification tools which illustrate soft-bodied algal flora recorded from the sampling area of the project such as, Gutowski and Foerster (2009), Benthische Algen ohne Diatomeen und Characeen (http://www.lanuv.nrw.de/veroeffentlichungen/ arbeitsblatt/arbla9/arbla9start.htm), Stancheva et al. (2014), Soft-Bodied Stream Algae of California (http://dbmuseblade. colorado.edu/DiatomTwo/sbsac_site/index.php), ANSP Algae Image Database from the Phycology Section, Patrick Center for Environmental Research, Academy of Natural Sciences (http://diatom.acnatsci.org/AlgaeImage/).

\section{Approaches to apply soft-bodied algae as bioindicators}

The oldest approach to stream bioassessment is based on an indicator species concept where known environmental tol- erances of algal species are used to evaluate the water quality. Tolerances of algal species to environmental variables are determined by a non-quantitative ranking of the water quality characteristics of habitats in which taxa have been reported in extensive literature sources. For example, Palmer (1969) ranked algal species, genera and phyla according their tolerance to high organic pollution. VanLandingham (1982) provided autecological data for 161 cyanobacterial species in eight categories or "spectra" (e.g. $\mathrm{pH}$, saprobien, nutrient, halobion, temperature, general and specific habitat, and seasonality). Schmedtje et al. (1998) classified 138 soft-bodied benthic algal taxa in regards to trophic state.

The concept of "saprobien system" (Sladeček, 1973) and the weighted average equation of Zelinka and Marvan (1961) are a cornerstone for the development of biotic indices to assess a single stressor that are largely used in WFD of the EU (see for review Kelly, 2013; Poikane et al., 2014), but not adopted in the US large-scale bioassessment. Soft-bodied algal biotic indices are derived from a semi-quantitative data set with fine taxonomic resolution and relative quantification of the taxa. In contrast, multimetric indices of biotic integrity which include several structural and functional measures of algal communities assess the overall ecological condition are used in the US (Dolédec and Statzner, 2010). Soft-bodied algal metrics for multimetric indices of biotic integrity are constructed from a quantitative data set with absolute biovolume quantification of the taxa, but with variable taxonomic resolution due to the differences among the laboratory methods.

In this section we present both types of bioassessment indices in more detail, because they are the final step in the stream bioassessment and highly depend on the quality of the data obtained by the methods outlined in the preceding section.

\subsection{Biotic indices (BI)}

Rott et al. $(1997,1999)$ developed the first weighted average BIs for assessment of saprobic and trophic status of streams and rivers in Austria based on algae from all taxonomic groups. The index utilises numerical data from more than 1100 stream sites in Austria, combined with information from the literature with special attention to results relevant to the situations in Austrian running waters (Rott et al., 1999). These numerical models used species indicator values (related to species optima) ranging from 0 to 5 as predictors of water quality parameters. Lists with more than 500 soft-bodied algae species with species specific saprobic or trophic values (total phosphorus (TP), nitrate $\left(\mathrm{NO}_{3}\right)$ and/or ammonium $\left(\mathrm{NH}_{4}\right)$ concentration as proxy for nutrients) and indicator weight were developed (Rott et al., 1997, 1999). To calculate the indices for a sampling site, the species relevant indicator value and weight are used, weighted additionally by the frequency information from the microscopic analysis (Sladeček, 1973; Rott et al., 1997, 1999), although the calculation procedure allows for the use of presence-absence data for the whole algal community (Rott et al., 1997). In this way, ecological status of streams and rivers is evaluated according to five classes (high, good, moderate, poor, bad) based on three saprobic and five trophic condition classes (Rott et al., 1997, 1999; Pfister and Pipp, 2013). Potapova et al. (2004) noted that the underlying assumption of 
inference indices, based on the weighted averaging of species indicator values, is that the shapes of species response curves along the environmental gradient are unimodal and symmetrical., However Sladeček (1973) and Rott et al. (1997) have also recognized that algal species do not necessarily follow unimodal or symmetrical environmental distribution patterns and have estimated the relative probability of species occurrence across several saprobic zones. Nevertheless, to simplify the calculation and representation of results, they based their indices on a single indicator value for each species (Potapova et al., 2004). These indices include all taxonomic groups, but evaluation based only on diatoms although possible, has lower predictive power (Rott et al., 1999). Using a similar approach, a long list with diatoms and soft-bodied algae characteristics for reference conditions in different bioregions in Austria had been developed (Pfister and Pipp, 2013) in order to assess deviations of trophic and saprobic states from the respective bioregion-specific reference conditions.

Both saprobic and trophic indices of Rott et al. (1997, 1999) are successfully used in the stream ecological classification in Germany, but they are not applicable in Norway, because many local benthic algae are not available in the indicator lists (Schneider and Lindstrøm, 2011). One explanation for this variation is the predominance of soft waters in Norway and hard waters in central Europe, but in Scandinavia other factors are probably also important, such as that much of the $\mathrm{P}$ may be organic, especially where water drains from peatlands (Whitton, 2013). Furthermore, the species optima and tolerances for $\mathrm{pH}$, conductivity, $\mathrm{TP}$ and $\mathrm{NO}_{3}$ of common softbodied algal species in Norway and Austria are significantly different with generally higher values for Austria (Rott and Schneider, 2014)

Consequently, Schneider and Lindstrøm (2011) developed new periphyton index of trophic status (PIT) for Norway, derived from 556 samples (over 350 river sites), and indicator values for nutrient optima for 153 soft-bodied algal species considering TP as a proxy for trophic status. A long history of acidification impairment of surface waters in Scandinavia caused by sulfur and nitrogen emissions, established softbodied algae as early warning indicators in regular monitoring programs in Norway (Knutzen et al., 1980). Schneider and Lindstrøm (2009) created the acidification index periphyton (AIP) for Norway, based on 608 samples (318 river sites), and indicator values for $\mathrm{pH}$-optima for 108 soft-bodied alga species are calculated ranging from $\mathrm{pH} 5.13$ to 7.50. The data obtained between 1976 and 2010 in Norway are used for the development and testing of the new soft-bodied algae indices (Lindstrøm et al., 2004; Schneider and Lindstrøm, 2009, 2011; Schneider 2011; Schneider et al., 2013).

Taxa optima for both of these indices are calculated from presence-absence datasets by averaging $\mathrm{pH}$ and $\log _{10}$-trans formed TP at the sites where particular taxa occur. This method is a modification for qualitative datasets of the weighted averaging method (ter Braak and van Dam, 1989), which is considered a practical and robust approach for quantifying species responses to environmental parameters (Ponader et al., 2007). Authors initially calculated weighted optima, including species relative abundance estimated on a 5-point scale or as a percent bottom cover, but concluded that semi- quantitative data provided no better fit with TP concentration than presence-absence data (Schneider and Lindstrøm, 2011). The difference between a weighted averaging inference model and the indices mentioned above is essentially the numerical scale on which species indicator values are expressed and estimations are made. In inference models, species optima are absolute values of the parameter that is estimated, in contrast to their expression on a convenient scale, ranging in value from 0 to 5 (Potapova et al., 2004). The final values of the AIP and PIT indices are absolute values, since they are calculated as a sum of the indicator values of all indicator species recorded in a given sample divided by the number of indicator species.

Regardless of the fact that the statistical power of weighted averaging might be lowered by the presence-absence data set, Schneider et al. (2013) demonstrated that both soft-bodied indices (AIP and PIT) are significantly correlated to five diatombased indices for $\mathrm{pH}$, trophic and pollution states widely used in Europe and to corresponding environmental parameters $(\mathrm{pH}$ and TP), tested in 52 rivers in Norway. These studies suggest that indices based on the presence or absence of soft-bodied algae are excellent for broad surveys involving a large number of sites (Whitton, 2013). Furthermore, Schneider and Lindstrøm (2011) provided evidence that use of "morphospecies" categories for some filamentous genera which require reproductive structures for species identification (i.e. Mougeotia, Spirogyra, Zygnema, and Oedogonium), although of poor taxonomic value (Drummond et al., 2005), might be useful and practical eutrophication indicators. Finally, soft-algal indicator lists of Schneider and Lindstrøm $(2009,2011)$ demonstrate the importance of species-level identification, because only in a few algal genera do all species have similar optima in respect to TP (e.g. desmids, Gongrosira, Draparnaldia). Univariate BIs infer individual stressor conditions, but indices inferring nutrients and $\mathrm{pH}$ should be particularly useful, because these environmental constituents are highly variable due to weather and diurnal variation of metabolic processes (Stevenson et al., 2010, Whitton, 2013). According to Stevenson (2010), nutrient and $\mathrm{pH}$ BIs can be used to refine stressor-response relationships, to resolve threshold levels, and to establish criteria for stressors. Schneider and Lindstrøm (2011) reported a major threshold of $10 \mu \mathrm{g} \cdot \mathrm{L}^{-1} \mathrm{TP}$ for the relationship between PIT and TP concentrations.

If the soft-bodied algal weighted average IBs are used in isolation, only three stressors can be evaluated (e.g. organic pollution, nutrient load, $\mathrm{pH}$ ) among multiple potential stressors and natural causes of community variation (Cairns and Pratt, 1993). This problem could be overcome by indices based on the actual species expected in a particular stream site (Kelly, 2013). A good example is the approach developed in Germany. Based on results from multivariate and univariate analysis of the local algal flora and environmental variables, 232 soft-bodied algal species are classified into four assessment categories according to their sensitivity to trophy, saprobity, and contaminants, in conjunction with to their distribution pattern among variable geomorphology (Foerster et al., 2004; Gutowski et al., 2004; and Schaumburg et al., 2004, 2012). This method can avoid the problems with single-stressor IBs, which can not detect taxonomic change due to other factors than those for which the index has been calibrated, but requires 
good understanding of algal communities from different geographic areas and water types.

\subsection{Multimetric indices of biotic integrity (IBI)}

Several diatom IBIs have been developed in the past decade and serve as a main tool together with macroinvertebrate IBIs in stream bioassessment programs in the United States. Similarly, the requirements of the European WFD for an integrative assessment of ecological condition of streams and rivers are frequently achieved through diatom multimetric indices, one of which includes algal biomass (chlorophyll $a$ ) as community metric (Delgardo et al., 2010). Regulatory methodology for development and application of this bioassessment tool are suggested (Hering et al., 2006). The standard approach in the construction of diatom IBIs are outlined by Stevenson et al. (2010) and literature cited therein. The most critical step in any IBI development is the selection of the metrics - the ultimate goal is to choose metrics that represent as many levels of ecological organization as possible, following the original concept of Karr (1981). The soft-bodied algal community attributes that have been used to assess ecological conditions in streams are both structural and functional, the latter together with chlorophyll $a$ and ash-free dry mass measurements are representative for the entire benthic community, including diatoms, bacteria and fungi (Stevenson et al., 2010). Structural taxonomic characteristics of soft-bodied algal communities, indicator species and indicator guilds which combine a subset taxa with similar physiologies and ecosystem function are most often applied as biotic indices and as metrics in multimetric indices (Table 2). The value of IBIs is that they tend to be more linear than univariate BIs (Fore et al., 1994) and help to provide a summary index which simplifies communication of results by a convenient scoring scale, e.g. 0 to 100 (Stevenson et al., 2010). However, the meaning of IBIs has been questioned in regards to predictability, diagnostic power, lack of reason for high or low index values, the validity of summing heterogeneous metrics into a single measure of stream condition, blurring effects on one metric by effects on other metrics, etc. (see review by Dolédec and Statzner, 2010).

The exploration of soft-bodied algae community characteristics as supplemental metrics in diatom IBIs began with work by Hill et al. $(2000,2003)$ which include non-taxonomic and functional measures of entire benthic algal communities, i.e. chlorophyll $a$, ash-free dry mass, and alkaline phosphatase activity in two studies of streams in the eastern US (as part of EMAP), each comprised of nearly 300 samples. In addition, two taxonomic metrics containing soft-bodied algae (relative abundance of cyanobacteria and relative genera richness) were evaluated (Hill et al., 2000). Despite the noted relationship between both taxonomic metrics and some environmental variables, they were not responsive to water-quality constituents (Hill et al., 2000).

Porter (2008) and Porter et al. (2008) tested the efficacy of algal-community metrics calculated from 976 stream and river samples collected across the United States (as part of NAWQA) and their national and regional relations with water chemistry. Several metrics showed one or more significant correlations to nutrient and suspended-sediment concentrations including soft-bodied algal species richness and relative abundance of eutrophic, sestonic and motile algae determined from literature sources. A promising metric of trophic condition is the relative abundance of $\mathrm{N}_{2}$-fixing, heterocystous cyanobacteria combined with diatoms containing cyanobacterial endosymbionts, Epithemia, Rhopalodia and Denticula, which showed a negative correlation with $\mathrm{N}$ concentration (Porter et al., 2008). However, the presence of endosymbionts in Denticula has not been confirmed for North American species (Lowe, 2003).

The current development of soft-bodied algal metrics consists of empirical evaluation of indicator species from studied data sets, in contrast to autecological guild metrics based on literature data from distant geographical locations. Danielson et al. (2011), in a survey of 193 wadeable streams in Maine, used the weighted-average approach to compute species optima for watershed disturbances (e.g. TP, total nitrogen (TN), conductivity, \% land use that is no longer forest or wetland) and to categorize the algal species based on their sensitivity and tolerance to disturbance. Optima for 41 soft-bodied algal taxa are calculated separately from diatoms based on $\log _{10}$-transformed density to avoid distortion of relative abundances by large densities of cyanobacteria. In this way, authors distinguished many sensitive algal taxa (such as species belonging to Audouinella, Batrachospermum, Calothrix, Tolypothrix, Mougeotia, Zygnema, Ulothrix), but failed to determine disturbance tolerant soft-bodied algal species. However, metrics using proportion sensitive algal species including diatoms, and those based on soft-bodied algae alone showed significant correlation with \% developed land cover, in contrast to biomass and some taxonomic metrics (such as total species richness, richness and relative abundance of green algae, red algae and cyanobacteria) which were not correlated with anthropogenic stressors (Table 2).

Potapova and Carlisle (2011) developed diatom IBIs for over 1,000 NAWQA Program sites in five geographical regions across conterminous US. They used Indicator species analysis (Dufrêne and Legendre, 1997) to identify diatom and softbodied algal species associated with reference and disturbed sites, which are a priory classified based on watershed disturbance. As result, only 34 soft-bodied algal taxa (or morphological groups) were determined to be possible indicators of reference or disturbed sites, and their inclusion as metric did not improve the classification accuracy of diatoms IBIs. Potapova and Carlisle (2011) attributed the poor performance of soft-bodied algal metrics to the taxonomic method which precludes from species level identification and recommended development of new methods that better characterize the softbodied algal communities.

Fetscher et al. (2014) constructed the first IBIs based on soft-bodied algae alone derived from more than 451 stream samples collected predominantly in southern California (SWAMP, modified field method by Fetscher et al., 2009, and novel taxonomic method by Stancheva et al., 2012a). Soft-bodied algal metrics were taxonomic - algal phyla, indicator species and indicator guilds, and were expressed in two ways: proportion of total biovolume (relative biovolume), and proportion of total species number (relative species richness). Indicator species had been evaluated empirically from 
Table 2. Structural and functional attributes of the stream benthic soft-bodied algae community used as metrics in IBIs and reported relationships with environmental variables. Positive relationships are in regular font, negative relationships are italicized. $(*)$ indicates that metric is calculated as proportion from the entire assemblage, including "living" diatom cells. "Algae" refers to entire algal assemblage, including diatoms, "SBA" refers to soft-bodied (non-diatom) algae only.

\begin{tabular}{|c|c|c|}
\hline $\begin{array}{l}\text { Solt-bodied algal } \\
\text { community attribute }\end{array}$ & $\begin{array}{l}\text { IBI metric relationship } \\
\text { with environmental variables }\end{array}$ & References \\
\hline \multicolumn{3}{|l|}{ Biomass category } \\
\hline Total biovolume & & $\mathrm{a}, \mathrm{m}$ \\
\hline Total biovolume* & $\mathrm{NO}_{2}+\mathrm{NO}_{3}^{\mathrm{e}}, T S S^{\mathrm{e}}$ & $\mathrm{a}, \mathrm{e}$ \\
\hline Cell density & & $\mathrm{a}$ \\
\hline Cell density* & $T S S^{\mathrm{e}}$ & $e, f$ \\
\hline Ash-free dry mass (AFDM)* & $\begin{array}{l}\% \text { urban and suburban land }{ }^{\mathrm{c}}, \% \text { sand and fine sediments } \\
\text { c }\end{array}$ & $\mathrm{a}, \mathrm{c}, \mathrm{d}, \mathrm{j}, \mathrm{o}$ \\
\hline Chlorophyll $a(\mathrm{Chl} a)^{*}$ & $\begin{array}{l}\% \text { urban and suburban land }{ }^{c}, \text { color }^{c}, \mathrm{Fe}^{\mathrm{c}}, \text { canopy }^{\mathrm{d}}, \mathrm{Cl}^{\mathrm{d}} \text {, can- } \\
\text { nel width }\end{array}$ & $\mathrm{a}, \mathrm{c}, \mathrm{d}, \mathrm{f}, \mathrm{k}, \mathrm{o}$ \\
\hline Autotrophic index $(\mathrm{AFDM} / \mathrm{Chl} a)^{*}$ & & $\mathrm{j}, \mathrm{o}$ \\
\hline \multirow{2}{*}{\multicolumn{3}{|c|}{$\begin{array}{l}\text { Taxonomic composition category } \\
\text { Indicator guilds category, Indicator species category, } \\
\text { Nutrient stoichiometry, Metabolic rates }\end{array}$}} \\
\hline & & \\
\hline Species richness* & $\begin{array}{l}\mathrm{NH}_{4}^{\mathrm{e}}, \mathrm{TN}^{\mathrm{e}}, \mathrm{TP}^{\mathrm{e}}, \mathrm{PO}_{4}^{\mathrm{e}}, \mathrm{TSS}^{\mathrm{e}}, \% \text { agriculture land }{ }^{\mathrm{e}}, \% \text { forested } \\
\text { land }^{\mathrm{e}}\end{array}$ & $\mathrm{a}, \mathrm{e}$ \\
\hline Relative genera richness* & $\mathrm{Cl}^{\mathrm{c}}, \mathrm{Fe}^{\mathrm{c}}, \mathrm{Mn}^{\mathrm{c}}$ & $\mathrm{a}, \mathrm{c}$ \\
\hline Genera richness & & $\mathrm{f}$ \\
\hline Division richness* & & $\mathrm{f}$ \\
\hline Shannon index* & & $\mathrm{g}, \mathrm{o}$ \\
\hline Cyanobacteria $(\mathbf{R A}) *$ & $\mathrm{SiO}_{2}^{\mathrm{c}}$, agriculture + all human disturbance in riparian zone ${ }^{\mathrm{c}}$ & $\mathrm{a}, \mathrm{c}, \mathrm{f}$ \\
\hline Cyanobacteria non-heterocystous (RB, RSR) & & $\mathrm{m}$ \\
\hline Chlorophyta (RA)* & & $\mathrm{a}, \mathrm{f}$ \\
\hline Chlorophyta (RB) & land use ${ }^{b}$ & $\mathrm{~b}$ \\
\hline Chlorophyta excl. Zygnemataceae (RB, RSR) & & $\mathrm{m}$ \\
\hline Zygnemataceae (RB, RSR) & & $\mathrm{m}$ \\
\hline Rhodophyta (RA)* & & $\mathrm{a}, \mathrm{f}$ \\
\hline Rhodophyta (RB, RSR) & & $\mathrm{m}$ \\
\hline \multicolumn{3}{|l|}{ Indicator guilds category } \\
\hline $\begin{array}{l}\mathrm{N}_{2} \text {-fixing heterocystous } \\
\text { cyanobacteria (RB, RSR) }\end{array}$ & & $\mathrm{m}, \mathrm{n}$ \\
\hline $\mathbf{N}_{2}$-fixing algae $(\mathbf{R A}) *$ & $\begin{array}{l}\% \text { forested land }{ }^{\mathrm{e}}, \mathrm{NO}_{2}+\mathrm{NO}_{3}^{\mathrm{e}}, \mathrm{TN}^{\mathrm{e}} \\
\% \text { agriculture }+ \text { urban land }\end{array}$ & $\mathrm{e}$ \\
\hline CRUS (RB) & land use $\mathrm{b}^{\mathrm{b}}$ & $\mathrm{b}$ \\
\hline ZHR (RR) & land use ${ }^{\mathrm{b}}$ & $\mathrm{b}$ \\
\hline Sestonic algae $(\mathbf{R A}) *$ & $\begin{array}{l}\mathrm{NH}_{4}^{\mathrm{e}}, \mathrm{TN}^{\mathrm{e}}, \mathrm{TP}^{\mathrm{e}}, \mathrm{PO}_{4}^{\mathrm{e}}, \mathrm{TSS}^{\mathrm{e}}, \% \text { agriculture+urban land } \\
\text { forested land }\end{array}$ & $\mathrm{e}$ \\
\hline Motile algae (RA)* & $\begin{array}{l}\mathrm{NH}_{4}^{\mathrm{e}}, \mathrm{NO}_{2}+\mathrm{NO}_{3}^{\mathrm{e}}, \mathrm{TN}^{\mathrm{e}}, \mathrm{TP}^{\mathrm{e}}, \mathrm{PO}_{4}^{\mathrm{e}}, \mathrm{TSS}^{\mathrm{e}}, \% \text { agriculture } \\
\text { land } \\
\text { e }, \% \text { forested land }\end{array}$ & $\mathrm{e}$ \\
\hline \multicolumn{3}{|l|}{ Indicator species category } \\
\hline Sensitive SBA (RB)* & $\%$ developed land cover ${ }^{\mathrm{a}}$ & a \\
\hline Sensitive algae $(\mathbf{R B})^{*}$ & $\%$ developed land cover ${ }^{\mathrm{a}}$ & a \\
\hline Eutrophic SBA (RA)* & $\mathrm{TN}^{\mathrm{e}}, \mathrm{TP}^{\mathrm{e}}, \mathrm{PO}_{4}^{\mathrm{e}}, \%$ agriculture land ${ }^{\mathrm{e}}, \%$ forested land $\mathrm{e}^{\mathrm{e}}$ & e \\
\hline Eutrophic algae (RA)* & $\begin{array}{l}\mathrm{NO}_{2}+\mathrm{NO}_{3}^{\mathrm{e}}, \mathrm{TN}^{\mathrm{e}}, \mathrm{TP}^{\mathrm{e}}, \mathrm{PO}_{4}^{\mathrm{e}}, \mathrm{TSS}^{\mathrm{e}}, \% \text { agriculture+urban } \\
\text { land }^{\mathrm{e}}, \% \text { forested land }\end{array}$ & $\mathrm{e}$ \\
\hline Low TP SBA indicators (RSR) & land use $\mathrm{b}^{\mathrm{b}}$ & $\mathrm{b}$ \\
\hline High DOC SBA indicators (RB, RSR) & land use $\mathrm{b}^{\mathrm{b}}$ & $\mathrm{b}$ \\
\hline High Cu SBA indicators (RSR) & land use $\mathrm{b}^{\mathrm{b}}$ & $\mathrm{b}$ \\
\hline Non-reference conditions & land use $\mathrm{b}^{\mathrm{b}}$ & $\mathrm{b}$ \\
\hline \multicolumn{3}{|l|}{ SBA indicators (RB, RSR) } \\
\hline TP algal indicators (RA)* & & $\mathrm{g}$ \\
\hline Conductivity algal indicators (RA)* & & $\mathrm{i}$ \\
\hline DIN algal indicators $(\mathbf{R A}) *$ & & $\mathrm{i}$ \\
\hline
\end{tabular}


Table 2. Continued.

\begin{tabular}{|c|c|c|}
\hline $\begin{array}{l}\text { Sofit-bodied algal } \\
\text { community attribute }\end{array}$ & $\begin{array}{l}\text { IBI metric relationship } \\
\text { with environmental variables }\end{array}$ & References \\
\hline \multicolumn{3}{|l|}{ Nutrient content } \\
\hline $\begin{array}{l}\text { Algal C/SA, N/SA, P/SA } \\
\text { Nutrient stoichiometry } \\
\text { C:N/SA } \\
\text { N:P/SA } \\
\text { Metabolic rates }\end{array}$ & & $\begin{array}{c}\mathrm{j} \\
\mathrm{j}, \mathrm{o}\end{array}$ \\
\hline Alkaline phosphatase activity* & $\begin{array}{l}\text { agriculture in riparian zone }{ }^{\mathrm{c}}, \mathrm{TP}^{\mathrm{d}}, \text { canopy }^{\mathrm{d}} \text {, all disturbance } \\
\text { in riparian zone }{ }^{\mathrm{c}} \text {, channel substrate, width, and depth }\end{array}$ & $\mathrm{c}, \mathrm{d}, \mathrm{f}$ \\
\hline
\end{tabular}

References: Danielson et al., 2011 (a); Fetscher et al., 2014 (b); Hill et al., 2000 (c); Hill et al., 2003 (d); Porter et al., 2008 (e); Griffith et al., 2002 (f); Leland and Porter 2001 (g); Munn et al., 2002 (i); O‘Brien and Wehr 2010 (j); Pan et al., 1999 (k); Stancheva et al., 2012a (m); Stancheva et al., 2013b (n); Vis et al., 1998 (o). Abbreviations: IBI - multimetric indices of biotic integrity, RB - relative biovolume, RA relative abundance based on cell numbers, RSR - relative species richness, SA - surface area, CRUS - Cladophora glomerata + Rhizoclonium hieroglyphicum + Ulva flexuosa + Stigeoclonium spp., ZHR - Zygnemataceae + heterocystous cyanobacteria + Rhodophyta, DIN - dissolved inorganic nitrogen, TN-total nitrogen, TP - total phosphorus, DOC - dissolved organic carbon, TSS - total suspended solids, WT - water temperature.

the validation dataset because literature sources do not provide sufficient autecological data. Indicator species analysis (Dufrêne and Legendre, 1997) was performed on species absolute biovolume data. There were 81 soft-bodied algal species identified to correlate significantly with either low or high concentrations of TP, TN, dissolved organic carbon (DOC), or dissolved copper $(\mathrm{Cu})$ (see Table 1 for values of water chemistry parameters). Several soft-bodied algal metrics passed the screening process for IBI development, including two indicator guilds with contrasting responses to local stressors, each based on a subset of taxa with similar function in the ecosystem. The guild metric with negative response to increasing levels of generalized stressor combined a proportion of Zygnemataceae, heterocystous cyanobacteria and red algae, in agreement with previous observations that each group is sensitive to particular nutrient or other water chemistry constituents (Stancheva et al., 2012a). The opposite metric consists of proportions of Cladophora glomerata L., Rhizoclonium hieroglyphicum (C. Agardh) Kütz., Ulva flexuosa Wulfen, and Stigeoclonium spp., which have been evaluated as the strongest indicators of high levels of TN, TP, DOC, $\mathrm{Cu}$ and non-reference conditions (Tables 1 and 2, Figure 1), except for Stigeoclonium which did not fulfill statistical criteria because of its rare distribution in the study area.

Selected soft-bodied algal metrics were incorporated in 17 hybrid IBIs containing diatom metrics also and in 3 softbodied algal IBIs. Some of the soft-bodied algal metrics included in the hybrid IBIs were designed to reduce laboratory efforts, such as species level taxonomy resolution without biovolume estimate $v s$. genus level identification with biovolume data. In addition, 5 diatom IBIs were constructed from the same data set. The best performing IBI in regards to the discriminatory power among the three site disturbance classes, and responsiveness to anthropogenic stress, signal-to-noise ratio, metric redundancy, and degree of indifference to natural gradients contains five diatom and three soft-bodied algal metrics (species indicators of low TP, high $\mathrm{Cu}$ and high DOC, ex-

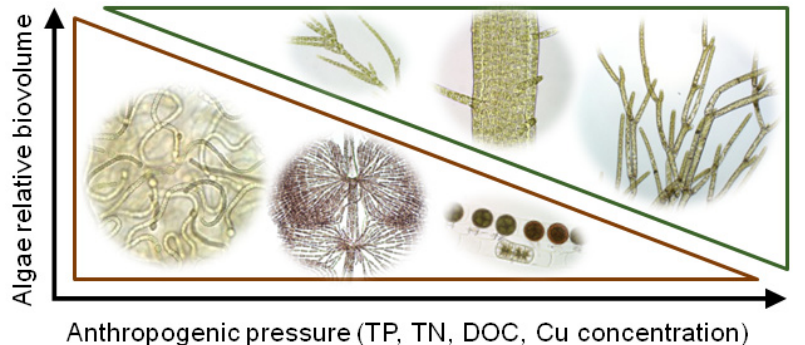

Fig. 1. Diagram visualizing the opposite distributional trends of two guild algal metrics along the generalized land use gradient used in stream IBIs in California by Fetscher et al., 2014. Legend: Lower-left triangle indicates the ZHR guild metric consisting of Zygnemataceae, heterocystous cyanobacteria and red algae; Upper-right triangle indicates the CRUS guild metric consisting of Cladophora glomerata L., Rhizoclonium hieroglyphicum (C. Agardh) Kütz., Ulva flexuosa Wulfen, and Stigeoclonium spp. Abbreviations: see Table 1.

pressed as relative species richness). The comparison between both types of single-algal IBIs showed that the soft-bodied algal IBIs separate best the disturbed and intermediate sites, and respond negatively to canopy cover and slope, while diatom IBIs discriminate better intermediate and reference sites, but are responsive to more natural gradients, such as stream order, watershed area and percent fine substrate (Fetscher et al., 2014).

In summary, the structural soft-bodied algal metrics currently applied in stream IBIs are variable. Depending on the taxonomic method, they can be expressed as relative biovolume (Fetscher et al., 2014) or relative abundance (based on cell density, Danielson et al., 2011; Potapova and Carlisle, 2011), with live diatom cells included or not in the counts. It seems that empirically evaluated local soft-bodied algal indicator species and guild metrics best respond to anthropogenic stress. Furthermore, Fetscher et al. (2014) demonstrated that species level or lower taxonomic resolution is needed for 
meaningful algal IBIs, because they rely on soft-bodied indicator species, not genera. Hill et al. (2003) suggested that regardless of the approach taken, the resulting index should be composed of biological metrics that have clear relationship to specific environmental stressors, in consideration of their variability at different spatial scales (reach, stream, river basin).

\section{Soft-bodied algae as bioindicators of nutrients}

Nutrients are a high-priority water quality concern, because they are a common cause of stream impairment. They are typically monitored by discrete sampling of ambient concentrations, which can be highly variable, even over a short duration, and these data are rarely indicative of the potential for ecosystem impacts (Whitton and Kelly, 1995). Historically, two approaches have been taken with regards to biological monitoring of nutrients: an ecosystem approach, in which algal biomass and productivity are used to infer nutrient impact, and an autecological approach, in which indicator species and BIs are used as nutrient assessment tools (Borchardt, 1996). Indeed, functional algal attributes are less commonly used, although they are informative for ecosystem condition (Kelly, 2013).

Nutrient enrichment typically stimulates algal growth in flowing waters and many studies demonstrate threshold algal response of approximately $30 \mu \mathrm{g} \cdot \mathrm{L}^{-1} \mathrm{TP}$ and $40 \mu \mathrm{g} \cdot \mathrm{L}^{-1} \mathrm{TN}$ above which chlorophyll values are substantially higher (for a review see Dodds et al., 1997; Stevenson et al., 2012). Benthic chlorophyll values above $100 \mathrm{mg} \cdot \mathrm{m}^{-2}$ have been considered excessive, representing a critical level for an aesthetic nuisance (Welch et al., 1988). As system becomes more productive, different species of algae become more competitive, including toxin-producing cyanobacteria (Fetscher et al., 2015), and species composition shifts occur. Usually, nuisance algal growths in streams and rivers are monitored by quantitative sampling of algal biomass. However, algal-nutrient interactions should be interpreted with care, because many studies have shown that factors other than nutrients (e.g., light, temperature, substratum type and availability, etc.) could be more important in determining algal biomass, species composition and structure (reviewed by Borchardt, 1996). According to Biggs (1996) biomass loss in streams is a function of algal community age, periodic sloughing losses of the mats, large losses due to disturbance events, such as floods, and grazing from invertebrates and fish during prolonged periods of hydrological stability. Therefore, attempts to generate dissolved nutrient-benthic algal biomass models should be considered carefully (for review see Biggs, 2010).

On the other hand, algal growth can be limited by scarcity of macronutrients and micronutrients, but the most frequent limiting factors are nitrogen $(\mathrm{N})$ and phosphorus $(\mathrm{P})$, because demand is high relative to their availability. The concept of single-nutrient limitation which postulates that an algal species can be limited by only one nutrient at a time does not usually apply to algal communities where diverse species may be limited by different nutrients simultaneously (Borchardt, 1996). Francoeur et al. (1999) and Dodds and Welch (2000) showed that N, P or other nutrients can be colimiting for stream periphyton. Furthermore, the availability of both nutrients may vary geographically; for instance, $\mathrm{P}$ is in short supply in the north part of the US, N in the Pacific Southwest and both nutrients in the Pacific Northwest (Borchardt, 1996 and literature therein).

Nutrient limitation both by $\mathrm{P}$ and $\mathrm{N}$ in streams is readily accessible by the functional responses of the benthic algal community, such as alkaline phosphatase activity (APA) and atmospheric $\mathrm{N}$ fixation, which are expected to decrease with nutrient enrichment (Hill et al., 2000; Stancheva et al., 2013b). Indeed, APA measurements of entire periphyton in large-scale stream bioassessments showed contradicting results (Hill et al., 2000, 2003; Griffith et al., 2002, Table 2), which could be explained by multiple ecological processes operating at different spatial and temporal scales in complex ecological systems (Pan et al., 1999). According to Mulholland and Rosemond (1992), APA is a valuable indicator of $\mathrm{P}$ limitation, affecting algal species composition, but does not consistently affect algal biomass (chlorophyll $a$, total biovolume) and productivity (carbon fixation rate, chlorophyllspecific carbon fixation rate).

Under conditions of moderate P limitation, some freshwater green algae, such as Draparnaldia, Chaetophora, Stigeoclonium (Gibson and Whitton, 1987), and red algae, e.g. Batrachospermum, Sheathia, Sirodotia (Sheath and Hambrook, 1990) form different types of "surface" phosphatases (Whitton et al., 1998). In addition, they develop prominent hairs where the phosphatase is located, functioning to increase the surface area of phosphorus uptake (Whitton, 1988). This activity is easy to assay for practical monitoring purposes by use of substrates, such as p-nitrophenyl phosphate, upon whose hydrolysis releases the colored p-nitrophenol (Whitton, 1991; Whitton et al., 2002). Similarly, conditions of inorganic phosphate deficiency influence the trichome morphology of cyanobacteria belonging to the Rivulariaceae by inducing formation of long colorless multicellular hairs, which are the sites of phosphomonoesterase activity for utilizing organic phosphates (Whitton and Mateo, 2012). The members of Rivulariaceae also possess heterocysts and are able to fix atmospheric nitrogen during periods of high inorganic $\mathrm{P}$ supply (Whitton and Mateo, 2012). Mateo et al. (2010) observed that in Pyrenees calcareous streams, $\mathrm{P}$ limitation is the main chemical factor to influence benthic cyanobacterial communities, including several heterocystous taxa, of which Rivularia was the most abundant. The authors proposed rapid methods for assessing longterm nutrient changes in a catchment, combining observations on macroscopically visible cyanobacteria with assays of surface phosphatase activity (Mateo et al., 2010).

$\mathrm{N}$ limitation of benthic algal communities from large stream data sets in southern California had been clearly indicated by the presence of $\mathrm{N}_{2}$-fixing heterocystous cyanobacteria and coccoid cyanobaterial endosymbionts in diatoms Rhopalodia and Epithemia (Stancheva et al., 2013b). Response thresholds in $\mathrm{N}_{2}$-fixers biovolume and nitrogenase gene expression obtained by real-time reverse transcriptase PCR were $0.075 \mathrm{mg} \cdot \mathrm{L}^{-1} \mathrm{NO}_{3}-\mathrm{N}, 0.04 \mathrm{mg} \cdot \mathrm{L}^{-1} \mathrm{NH}_{4}-\mathrm{N}$, and an $\mathrm{N}: \mathrm{P}$ ratio (by weight) of 15:1 (Stancheva et al., 2013b). Thus, rapid quantitative microscopic and molecular methods for nutrient 
monitoring can be based on $\mathrm{N}_{2}$-fixing cyanobacteria and endosymbiont-containing diatoms (Stancheva et al., 2013b). If these rapid and simple approaches proposed by Whitton (1991), Mateo et al. (2010) and Stancheva et al. (2013b) are incorporated in standard bioassessment of stream nutrient conditions, they could be beneficial also in monitoring air pollutionrelated atmospheric nitrogen deposition, which is a recognized threat to plant diversity in temperate and northern parts of Europe and North America (Bobbink et al., 2010), but its impact on stream ecosystems is largely unexplored.

\section{Concluding remarks}

This review shows that soft-bodied algae are valuable indicators of stream and river water quality, but holistic studies including all algal taxonomic groups are not yet common. The structural taxonomic attributes of soft-bodied algal communities are good measures of anthropogenic stress, but better understanding of the nature of this organism group is needed to make it meaningful and easy-to-use standard bioassessment tools. For instance, Stevenson and Smol (2003) suggested that the precision of algal indicators is improved when they are refined with regional datasets. It is particularly important for soft-bodied algae, which exhibit stronger geographical specialization than diatoms, which makes their applicability more locally restricted (Potapova and Carlisle, 2011; Schneider et al., 2012; Schneider and Rott, 2013).

Another important consideration in soft-bodied algae bioassessment application is the quality of taxonomic identifications which is central to biological assessment. The impact generated by taxonomical uncertainty and incompleteness usually transcends the limits of ecology and environmental management (Bortolus, 2008). Large-scale bioassessment surveys are designed with the objective to produce statistically valid assessments of biological conditions in streams (Hughes and Peck, 2008), but the fundamental key piece of biological information is a species of algae or any other organism selected as an indicator. Therefore, field sampling and taxonomic analysis should follow the best practices to provide a detailed list of microalgae and macroalgae identified to species level. The optimal level of taxonomic resolution for stream biomonitoring is still debated (reviewed by Rimet and Bouchez, 2012). Species level determination is considered the gold standard even if there are some disadvantages of using precise taxonomic resolution, mostly associated with high cost, time and the expertise demanded, and the possibility for more errors in identification (Konar and Iken, 2009). Biovolume quantification of soft-bodied algae is important during the initial accrual of data for development of algal IBIs, but metrics based on relative rather than absolute values have stronger relationships to water quality, and enable statistical significant evaluation of ecological tolerances (Danielson et al., 2011, Fetscher et al., 2014).

Once the algal attributes, such as an indicator species or stressor responsive ecological guilds, are determined to be statistically valid and included in IBIs as metrics, reducing the taxonomic efforts and cost for continuing routine monitoring might be appropriate similarly to microinvertebrate bioasessment (Gartzia De Bikuña et al., 2015). For example, one of the best performing hybrid IBIs for southern California includes three soft-bodied algal metrics which do not require biovolume data, but species level identification (Fetscher et al., 2014); thus, the reduction of taxonomic analysis efforts is possible by semi-quantitative estimate. All successfully applied BIs in European stream and river biomonitoring are based on algal presence-absence species level data, which confirmed the importance of fine taxonomic resolution. Further reduction of taxonomy efforts is feasible for causal assessments, such as of nutrient condition, which can be evaluated rapidly by microscopic or molecular methods based on ecological guilds, such as $\mathrm{N}_{2}$-fixing cyanobacteria alone, or in combination with red algae and Zygnemataceae (after Fetscher et al., 2014). Developing molecular methods for algal ecological guilds could be more realistic option then the molecular bioassessment of algae community composition, which is promising approach, but not applicable at this point (Manoylov, 2014).

Acknowledgements. Part of the discussed research was funded by the consolidated grants and the SWAMP Program of the California State Water Resources Control Board. We thank both anonymous reviewers for their valuable comments which improved the quality of the manuscript.

\section{References}

Acker F., 2002. Analysis of Soft Algae and Enumeration of Total Number of Diatoms in USGS NAWQA Program Quantitative Targeted-Habitat (RTH and DTH) Samples. Protocol P-1363. In: Charles D.F., Knowles C., and Davis R.S. (eds.), Protocols for the analysis of algal samples collected as part of the US Geological Survey National Water-Quality Assessment Program. Report 0206, Patrick Center for Environmental Research. The Academy of Natural Sciences, Philadelphia.

ANZECC, 2000. National Water Quality Management Strategy: The Australian and New Zealand Guidelines for Fresh and Marine Water Quality. Australian and New Zealand Environment and Conservation Council and Agriculture and Resourse Management Council of Australia and New Zealand, Canberra, Australia.

Biggs B.J.F., 1987. Effects of sample storage and mechanical blending on the quantitative analysis of river periphyton. Freshwater Biol., 18, 197-203.

Biggs B.J.F., 1996. Patterns in benthic algae of streams, In: Stevenson R.J., Bothwell M.L. and Lowe R.L. (eds.), Algal Ecology: Freshwater Benthic Ecosystems. Academic Press, San Diego, $31-56$.

Biggs B.J.F., 2010. Eutrophication of streams and rivers: dissolved nutrient-chlorophyll relationships for benthic algae. J. N. Am. Benthol. Soc., 19, 17-31.

Biggs B.J.F. and Kilroy C., 2000. Stream periphyton monitoring manual. National Institute of Water and Atmospheric Research for the New Zealand Ministry for the Environment, viewed 19 November 2013, available at: http://www.smf.govt.nz/results/ 5092_periphytonmanual.,pdf.

Bobbink R., Hicks K., Galloway J., Spranger T., Alkemade R., Ashmore M., Bustamante M., Cinderby S., Davidson E., Dentener F., Emmett B., Erisman J.W., Fenn M., Gilliam F., Nordin A., Pardo L. and De Vries W., 2010. Global assessment of nitrogen deposition effects on terrestrial plant diversity: a synthesis. Ecol. Appl., 20, 30-59. 
Borchardt M.A., 1996. Nutrients. In: Stevenson R.J., Bothwell M.L. and Lowe R.L. (eds.), Algal Ecology: Freshwater Benthic Ecosystems. Academic Press, San Diego, 184-228.

Bortolus A., 2008. Error cascades in the biological sciences: the unwanted consequences of using bad taxonomy in ecology. Ambio, 37, 114-118.

Brown L.R., May J.T. and Hunsaker C.T., 2008. Species composition and habitat associations of benthic algal assemblages in headwater streams of the Sierra Nevada, California. West N. Am. Naturalist, 68, 194-209.

Cairns J.J. and Pratt J.R., 1993. A history of biological monitoring using benthic macroinvertebrates. In: Rosenberg D.M. and Resh V.H. (eds.), Freshwater biomonitoring and benthic macroinvertebrates. Chapman and Hall, New York, 10-28.

Clean Water Act, 1972. Federal Water Pollution Control Act Amendments of 1972. Public Law 92-500.33.U.S.C.1251.

Danielson T.J., Loftin C.S., Tsomides L., DiFranco J.L. and Connors B., 2011. Algal bioassessment metrics for wadeable streams and rivers of Maine, USA. J. N. Am. Benthol. Soc., 30, 1033-1048.

Delgardo C., Pardo I. and Liliana G., 2010. A multimetric diatom index to assess the ecological status of coastal Galician rivers (NW Spain). Hydrobiologia, 644, 371-384.

Dodds W.K. and Welch E.B., 2000. Establishing nutrient criteria in streams. J. N. Am. Benthol. Soc., 19, 186-196.

Dodds W.K., Smith V.H. and Zander B., 1997. Developing nutrient targets to control benthic chlorophyll levels in streams: a case study of the Clark Fork River. Water Res., 31, 1738-1750.

Dolédec S. and Statzner B., 2010. Responses of freshwater biota to human disturbances: contribution of J-NABS to developments in ecological integrity assessments. J. N. Am. Benthol. Soc., 29, 286-311.

Douterelo I., Perona E. and Mateo P., 2004. Use of cyanobacteria to assess water quality in running waters. Environ. Pollut., 127, 377-384.

Drummond C.S., Hall J.D., Karol K.G., Delwiche C.F. and McCourt R.M., 2005. Phylogeny of Spirogyra and Sirogonium (Zygnematophyceae) based on rbcL sequence data. J. Phycol., $41,1055-1064$.

Dufrêne M. and Legendre P., 1997. Species assemblages and indicator species: the need for a flexible asymmetrical approach. Ecol. Monogr., 67, 345-366.

European Commission, 2000. Directive 2000/60/EC of the European Parlament and Council, establishing a framework for Community action in the field of water policy. Official Journal of the European Community, 327, 1-72.

Fernandez-Piñas F., Leganés F., Mateo P. and Bonilla I., 1991. Bluegreen algae (cyanobacteria) as indicators of water quality in two Spanish rivers. In: Whitton B.A., Rott E. and Friedrich G. (eds.), Use of algae for monitoring rivers. Institut für Botanik. Universität Innsbruck, Innsbruck, 151-156.

Fetscher A.E., Busse L.B. and Ode P.R., 2009. Standard operating procedure for collecting stream algae samples and associated physical habitat and chemical data for ambient bioassessments in California. California State Water Resources Control Board Surface Water Ambient Monitoring Program (SWAMP) Bioassessment SOP 002.

Fetscher A.E., Sutula M.A., Busse L.B. and Stein E.D., 2013. Condition of California perennial, wadeable streams based on algal indicators. California State Water Resources Control Board Surface Water Ambient Monitoring Program (SWAMP) Final Technical Report.

Fetscher A.E., Stancheva R., Kociolek J.P., Sheath R.G., Stein E.D., Mazor R.D., Ode P.R. and Busse L.B., 2014. Development and comparison of stream indices of biotic integrity using diatoms $v s$. non-diatom algae vs. a combination. J. Appl. Phycol., 26, 433450.

Fetscher A.E., Howard M.D.A., Stancheva R., Kudela R.M., Stein E.D., Sutula M.A., Busse L.B., Sheath R.G., 2015. Wadeable streams as widespread sources of benthic cyanotoxin production in California, USA. Harmful Algae, 49, 105-116.

Foerster J., Gutowski A.and Schaumburg J., 2004. Defining types of running waters in Germany using benthic algae: a prerequisite for monitoring according to the Water Framework Directive. J. Appl. Phycol., 16, 407-418.

Fore L.S., Karr J.R. and Conquest L.L., 1994. Statistical properties of an index of biotic integrity used to evaluate water resources. Can. J. Fish. Aquat. Sci., 51, 1077-1087.

Francoeur S.N., Biggs B.J.F., Smith R.A. and Lowe R.L., 1999. Nutrient limitation of algal biomass accrual in streams: seasonal patterns and a comparison of methods. J. N. Am. Benthol. Soc., $18,242-260$.

Frey D.G., 1977. Biological integrity of water: a historical approach. In: Ballentine R.K. and Guarraia L.J. (eds.), The integrity of water: a symposium. US Environmental Protection Agency, Washington, DC.

Gartzia De Bikuña B., López E., Leonardo J.M., Arrate J., Martínez A., Agirre A. and Manzanos A., 2015. Reduction of sampling effort assessing macroinvertebrate assemblages for biomonitoring of rivers. Knowl. Manag. Aquat. Ecosyst., 416, 08.

Gibson M.T. and Whitton B.A., 1987. Hair phosphatase activity and environmental chemistry in freshwater Stigeoclonium, Chaetophora and Draparnaldia (Chaetophorales). Brit. Phycol. J., 22, 11-22.

Goulden C.E., 2011. The need for capacity building for biomonitoring of lakes and streams in Asia. Lakes $\mathcal{E}$ Reservoirs: Research $\mathcal{E}$ Management, 16, 159-163.

Griffith M.B., Hill B.H., Herlihy A.T. and Kaufmann P.R., 2002. Multivariate analysis of periphyton assemblages in relation to environmental gradients in Colorado Rocky Mountain streams. $J$. Phycol., 38, 83-95.

Gutowski A. and Foerster J., 2009. Benthische Algen ohne Diatomeen und Characeen. Landesamt für Natur, Umwelt und Verbraucherschutz Nordrhein-Westfalen, viewed 3 April 2014, http://www.lanuv.nrw.de/veroeffentlichungen/arbeitsblatt/ arbla9/arbla9start.htm.

Gutowski A., Foerster J. and Schaumburg J., 2004. The use of benthic algae, excluding diatoms and Charales, for the assessment of the ecological status of running waters: a case history from Germany. Oceanol. Hydrobiol. Stud., 33, 3-15.

Hering D., Feld C.K., Moog O. and Ofenböck T., 2006. Cook book for the development of a Multimetric Index for biological condition of aquatic ecosystems: experiences from the European AQEM and STAR projects and related initiatives. Hydrobiologia, 566, $311-324$.

Hill B.H., Herlihy A.T., Kaufmann P.R., Stevenson R.J., McCormick F.H. and Burch Johnson C. 2000. Use of periphyton assemblage data as an index of biotic integrity. J. N. Am. Benthol. Soc., 19, $50-67$.

Hill B.H., Herlihy A.T., Kaufmann P.R., DeCelles S.J. and Borgh M.A.V., 2003. Assessment of streams of the eastern United States using a periphyton index of biotic integrity. Ecol. Indic., 2, 325 338.

Hughes R.M. and Peck D.V., 2008. Acquiring data for large aquatic resource surveys: the art of compromise among science, logistics, and reality. J. N. Am. Benthol. Soc., 27, 837-859. 
Jarlman A., Lindstrøm E.A., Eloranta P. and Bengtsson R., 1996. Nordic standard for assessment of environmental quality in running water. In: Whitton B.A. and Rott E. (eds.), Use of Algae for Monitoring Rivers II. Studia, Innsbruck, 17-28.

Johnson R.K., Hering D., Furse M.T. and Clarke R.T., 2006. Detection of ecological change using multiple organism groups: metrics and uncertainty. Hydrobiologia, 566, 115-137.

Karr J.R., 1981. Assessment of biotic integrity using fish communities. Fisheries, 6, 21-27.

Kelly M.G., 2006. A comparison of diatoms with other phytobenthos as indicators of ecological status in streams in northern England, Proceedings of the 18th International Diatom Symposium. Biopress, Bristol.

Kelly M.G., 2013. Data rich, information poor? Phytobenthos assessment and the Water Framework Directive. Eur. J. Phycol., 48, 437-450.

Kelly M.G., Cazaubon A., Coring E., DelUomo A., Ector L., Goldsmith B., Guasch H., Hürlimann J., Jarlman A., Kaweka B., Kwandrans J., Laugaste R., Lindstrøm E.A., Leitao M., Marvan P., Padisak J., Pipp E., Prygiel J., Rott E., Sabater S., van Dam H. and Vizinet J., 1998. Recommendations for routine sampling of diatoms for water quality assessments in Europe. J. Appl. Phycol., 10, 215-224.

Kelly M.G., King L., Jones R.I., Barker P.A. and Jamieson B.J., 2008. Validation of diatoms as proxies for phytobenthos when assessing ecological status in lakes. Hydrobiologia, 610, 125-129.

Knutzen J., Lingsten L., Lindstrøm E.A., Traaen T.S. and Aanes K.J., 1980. Nasjonalt programme for overvåking av vannresurser. Pilotprosjekt Målselva/Barduelva 1978. NIVA rapport, 1187, $1-55$.

Kolkwitz R. and Marsson M., 1908. Ökologie der pflanzlichen Saprobien. Ber. Dtsch. bot. Ges., 26, 505-519.

Konar B. and Iken K., 2009. Influence of taxonomic resolution and morphological functional groups in multivariate analyses of macroalgal assemblages. Phycologia, 48, 24-31.

Lavoie I., Vincent W.F., Pienitz R. and Painchaud J., 2004. Benthic algae as bioindicators of agricultural pollution in the streams and rivers of southern Québec (Canada). Aquat. Ecosyst. Health Manag., 7, 43-58.

Lazorchak J.M., Klemm D.J. and Peck D.V., 1998. Environmental Monitoring and Assessment Program-Surface Waters. Field Operations and Methods for Measuring the Ecological Condition of Wadeable Streams. EPA/620/R-94/004F. US Environmental Protection Agency, Washington, D.C.

Lazorchak J.M., Hill B.H., Averill D.K., Peck D.V. and Klemm D.J., 2000. Environmental Monitoring and Assessment ProgramSurface Waters: Field Operations and Methods for Measuring the Ecological Condition of Non-Wadeable Rivers and Streams. US Environmental Protection Agency, Cincinnati, $\mathrm{OH}$.

Lindstrøm E.A., Johansen S.W. and Saloranta T., 2004. Periphyton in running waters - long-term studies of natural variation. Hydrobiologia, 521, 63-86.

Loez C. and Topalián, M.L., 1997. Use of algae for monitoring rivers in Argentina with a speciel emphasis for the Reconquista river (region of Buenos Aires). In: Prygiel J., Whitton B.A., and Bukowska J. (eds.), Use of algae for monitoring rivers. Institut für Botanik, Universität Innsbruck, Innsbruck, 72-83.

Lowe R.L., 2003. Keeled and canaled diatoms. In: Wehr J.D. and Sheath R.G. (eds.), Freshwater Algae of North America: Ecology and Classification. Academic Press, San Diego, CA, 669-684.

Lowe, R.L. and Pan Y., 1996. Benthic algal communities as biological monitors. In: Stevenson R.J., Bothwell M.L. and Lowe R.L. (eds.), Algal Ecology: Freshwater Benthic Ecosystems. Academic Press, San Diego, 705-740.
Luce J.J., Cattaneo A. and Lapointe M.F., 2010. Spatial patterns in periphyton biomass after low-magnitude flow spates: geomorphic factors affecting patchiness across gravel-cobble riffles. J. N. Am. Benthol. Soc., 29, 614-626.

Manoylov K.M., 2014. Taxonomic identification of algae (morphological and molecular): species concepts, methodologies, and their implication for ecological bioassessment. J. Phycol., 50, 409-424.

Mateo P., Berrendero E., Perona E., Loza V. and Whitton B.A., 2010. Phosphatase activities of cyanobacteria as indicators of nutrient status in a Pyrenees river. Hydrobiologia, 652, 255-268.

Meyer J.L., Strayer D.L., Wallace J.B., Eggert S.L., Helfman G.S. and Leonard N.E., 2007. The contribution of headwater streams to biodiversity in river networks. J. Am. Water Resour. Assoc., 43, 86-103.

Moulton S.R., Kennen J.G., Goldstein R.M. and Hambrook J.A., 2002. Revised Protocols for Sampling Algal, Invertebrate, and Fish Communities as Part of the National Water-Quality Assessment Program. US Geological Survey, Open File Report 02-150, Reston, VA.

Mulholland P.J. and Rosemond A.D., 1992. Periphyton response to longitudinal nutrient depletion in a woodland stream: evidence of upstream-downstream linkage. J. N. Am. Benthol. Soc., 11, 405419.

Munn M.D., Black R.W. and Gruber S.J., 2002. Response of benthic algae to environmental gradients in an agriculturally dominated landscape. J. N. Am. Benthol. Soc., 21, 221-237.

Niemi G.J. and McDonald M.E., 2004. Application of ecological indicators, Annu. Rev. Ecol. Evol. Syst., 35, 89-111.

O'Brien P.J. and Wehr J.D., 2010. Periphyton biomass and ecological stoichiometry in streams within an urban to rural land-use gradient. Hydrobiologia, 657, 89-105.

Ontario Ministry of the Environment, 2011. An Algal Bioassessment Protocol for use in Ontario Rivers, viewed 20 November 2013, http://www.ene.gov.on.ca/environment/en/resources/ STDPROD_101254.html

Palmer C.M., 1969. A composite rating of algae tolerating organic pollution. J. Phycol., 5, 78-82.

Palmer M.A. and Poff N.L., 1997. The influence of environmental heterogeneity on patterns and processes in streams. J. N. Am. Benthol. Soc., 16, 169-173.

Pan Y., Stevenson R.J., Hill B.H., Kaufmann P.R. and Herlihy A.T., 1999. Spatial patterns and ecological determinants of benthic algal assemblages in Mid- Atlantic Highland streams. J. Phycol., 35, 460-468.

Pfister P. and Pipp E., 2013. Guidance on the monitoring of the biological quality elements - part A3 - phytobenthos. Federal Ministry of Agriculture, Forestry, Environment and Water Management Department VII A - 1012, Vienna.

Pipp E. and Rott E., 1996. Recent developments in the use of benthic algae (excluding diatoms) for monitoring rivers in Austria and Germany. In: Whitton B.A. and Rott E. (eds.), Use of algae for monitoring rivers II. Institut für Botanik, Universität Innsbruck, Innsbruck, 160-165.

Poikane S., 2015. Current state-of-art and future needs in algae-based monitoring from the perspective of the EU. In: Cantonati M., Kelly M.G., Rott E., Sabater S., Stevenson R.J., Whitton B.A., Schneider S., Shubert E.L., Van de Vijever B., Vis M.L. and Angeli N. (eds.), Use of algae for monitoring rivers and comparable habitats. Abstract Book, Trento, Italy, 23.

Poikane S., Zapoukas N., Borja S., Davies S.P., van de Bund W. and Birk S., 2014. Intercalibration of aquatic ecological assessment methods in the European Union: Lessons learned and way forward. Environ. Sci. Policy, 44, 237-246. 
Ponader K.C., Charles D.F. and Belton T.J., 2007. Diatom based TP and TN inference models and indices for monitoring nutrient enrichment of New Jersey streams. Ecol. Indic., 7, 79-93.

Porter S.D., 2008. Algal Attributes: An Autecological Classification of Algal Taxa Collected by the National Water-Quality Assessment Program. US Geological Survey Data Series 329. Viewed 25 November 2013, http://pubs.usgs.gov/ds/ds329/.

Porter S.D., Mueller D.K., Spahr N.E., Munn M.D. and Dubrovsky N.M., 2008. Efficacy of algal metrics for assessing nutrient and organic enrichment in flowing water. Freshwater Biol., 53, 10361054.

Potapova M.G. and Carlisle D.M., 2011. Development and application of indices to assess the condition of algal assemblages in US streams and rivers. Open-File Report 2011-1126, US Geological Survey.

Potapova M.G. and Charles D.F., 2005. Choice of substrate in algaebased water-quality assessment. J. N. Am. Benthol. Soc., 24, 415-427.

Potapova M.G., Charles D.F., Ponader K.C. and Winter D.M., 2004. Quantifying species indicator values for trophic diatom indices: a comparison of approaches. Hydrobiologia, 517, 25-41.

Resh V.H., 2008. Which group is best? Attributes of different biological assemblages used in freshwater biomonitoring programs. Environ. Monit. Assess. 138, 131-138.

Rimet F. and Bouchez A., 2012. Biomonitoring river diatoms: Implications of taxonomic resolution. Ecol. Indic., 15, 92-99.

Rodrigues L. and Bicudo D.C., 2001. Similarity among periphyton algal communities in a lentic-lotic gradi ent of the upper Parana river floodplain, Brazil. Revista Brasileira de Botânica, 24: 235248.

Rott E. and Schneider S.C., 2014. A comparison of ecological optima of soft-bodied benthic algae in Norwegian and Austrian rivers and consequences for river monitoring in Europe. Sci. Total. Environ., 475, 180-186.

Rott E., Hofmann G., Pall K., Pfister P. and Pipp E., 1997. Indikationsliste für Aufwuchsalgen in Fließgewässern in Österreich: Teil 1. Saprobielle Indication. Projekt des Bundesministeriums für Land- und Forstwirtschaft, Wasserwirtschaftskataster.

Rott E., Pipp E., Pfister P., Van Dam H., Ortler K., Binder N. and Pall K., 1999. Indikationslisten für Aufwuchsalgen in Österreichischen Fließgewässern: Teil 2. Trophieindication. Bundesministerium f. Land- und Forstwirtschaft, Zahl 41.034/08- IVA 1/97, Wien.

Rusanov A.G., Stanislavskaya E.V. and Ács É., 2012. Periphytic algal assemblages along environmental gradients in the rivers of the Lake Ladoga basin, Northwestern Russia: implication for the water quality assessment. Hydrobiologia, 695, 305-327.

Schaumburg J., Schranz C., Foerster J., Gutowski A., Hofmann G., Meilinger P., Schneider S. and Schmedtje U., 2004. Ecological classification of macrophytes and phytobenthos for rivers in Germany according to the Water Framework Directive. Limnologica, 34, 283-301.

Schaumburg J., Schranz C., Stelzer C., Vogel A. and Gutowski A., 2012. Instruction Manual for the Assessment of Running Water Ecological Status in Accordance with the Requirements of the EG-Water Framework Directive: Macrophytes and Phytobenthos, Bavarian Environment Agency, Augsburg.

Schmedtje U., Gutowski A., Hofmann G., Leukart P., Melzer A., Mollenhauer D., Schneider S. and Tremp H., 1998. Trophie kartierung von aufwuchs- und makrophytendominierten Fliesgewassern. Informationsberichte des Bayerischen Landesamtes fur Wasserwirtschaft 4/98.
Schneider S., 2011. Impact of calcium and TOC on biological acidification assessment in Norwegian rivers. Sci. Total Environ., 409, 1164-1171.

Schneider S.C. and Lindstrøm E.A., 2009. Bioindication in Norwegian rivers using non-diatomaceous benthic algae: the acidification index periphyton (AIP). Ecol. Indic., 9, 1206-1211.

Schneider S.C. and Lindstrøm E.A., 2011. The periphyton index of trophic status PIT: a new eutrophication metric based on nondiatomaceous benthic algae in Nordic rivers, Hydrobiologia, 665, 143-155.

Schneider, S.C., Lawniczak, A.E., Piciñska-Faltynowicz, J. and Szoszkiewicz, K., 2012. Do macrophytes, diatoms and nondiatom benthic algae give redundant information? Results from a case study in Poland. Limnologica, 42, 204-211.

Schneider S.C., Kahlert M. and Kelly M.G., 2013. Interactions between $\mathrm{pH}$ and nutrients on benthic algae in streams and consequences for ecological status assessment and species richness patterns. Sci. Total Environ., 444, 73-84.

Sheath R.G. and Hambrook J.A., 1990. Freshwater ecology. In: Cole K.M. and Sheath R.G. (eds.), Biology of the Red Algae. Cambridge University Press, New York, 423-454.

Sheath R.G. and Cole K.M., 1992. Biogeography of stream macroalgae in North America. J. Phycol., 28, 448-460.

Sládeček V., 1973. System of water quality from the biological point of view. Arch. Hydrobiol.-Beih. Ergebn. Limnol., 7, 1-218.

Stancheva R., Fetscher A.E. and Sheath R.G., 2012a. A novel quantification method for stream-inhabiting, non-diatom benthic algae, and its application in bioassessment. Hydrobiologia, 684, 225-239.

Stancheva R., Hall J.D. and Sheath R.G., 2012b. Systematics of the genus Zygnema (Zygnematophyceae, Charophyta) from Californian watersheds. J. Phycol., 48, 409-422.

Stancheva R., Hall J.D., McCourt R.M. and Sheath R.G., 2013a. Identity and phylogenetic placement of Spirogyra species (Zygnematophyceae, Charophyta) from California streams and elsewhere. J. Phycol., 49, 588-607.

Stancheva R., Sheath R.G., Read B.A., McArthur K.D., Schroepfer C., Kociolek J.P. and Fetscher A.E., 2013b. Nitrogen-fixing cyanobacteria (free-living and diatom endosymbionts): their use in southern California stream bioassessment. Hydrobiologia, 720, 111-127.

Stancheva R., Fuller C. and Sheath R.G., 2014. Soft-bodied stream algae of California, viewed 9 January 2015, http://dbmuseblade. colorado.edu/DiatomTwo/sbsac_site/index.php.

Stancheva R., Busse L., Kociolek J.P. and Sheath R.G., 2015. Standard Operating Procedures for Laboratory Processing and Identification of Stream Algae in California. California State Water Resources Control Board Surface Water Ambient Monitoring Program (SWAMP) Bioassessment SOP 0003.

Stevenson R.J., 2014. Ecological assessments with algae: a review and synthesis. J. Phycol., 50, 437-461.

Stevenson R.J. and Bahls L.L., 1999. Periphyton protocols. In: Barbour M.T., Gerritsen J. and Snyder B.D. (eds.), Rapid Bioassessment Protocols for Use in Wadeable Streams and Rivers: Periphyton, Benthic Macroinvertebrates, and Fish. EPA 841-B-99-002. United States Environmental Protection Agency, Washington, DC.

Stevenson R.J., Bothwell M.L. and Lowe R.L., 1996. Algal Ecology: Freshwater Benthic Ecosystems, Academic Press, San Diego, CA. 
Stevenson R.J., Pan Y. and van Dam H., 2010. Assessing environmental conditions in rivers and streams with diatoms. In: Smol J.P. and Stoermer E.F. (eds.), The Diatoms: Applications for the Environmental and Earth Sciences, 2nd edn. Cambridge University Press, Cambridge, MA, 2nd edition.

Stevenson R.J., Bennett B.J., Jordan D.N. and French R.D., 2012. Phosphorus regulates stream injury by filamentous green algae, DO, and $\mathrm{pH}$ with threshold in responses. Hydrobiologia, 695, 25 42.

Stoddard J.L., Larsen D.P., Hawkins C.P., Johnson R.K. and Norris R.H., 2006. Setting expectations for the ecological condition of streams: the concept of reference condition. Ecol. Appl., 16, $1267-1276$

ter Braak C.J.F. and van Dam H., 1989. Inferring $\mathrm{pH}$ from diatoms: a comparison of old and new calibration methods. Hydrobiologia, 178, 209-223.

USEPA, 2002. A SAB report: a framework for assessing and reporting on ecological condition. EPASAB-EPEC-02-009. US Environmental Protection Agency, Washington, DC.

USEPA, 2007. National Rivers and Streams Assessment: Field Operations Manual., EPA-841-B-07009. US Environmental Protection Agency, Washington, DC.

USEPA, 2008. National Rivers and Streams Assessment: Laboratory Methods Manual., EPA-841-B07-010. US Environmental Protection Agency, Office of Water and Office of Research and Development, Washington, DC.

VanLandingham S.L., 1982. Guide to the identification, environmental requirements and pollution tolerance of bluegreen algae (Cyanophyta). EPA-600/3-82-07.

Vis C., Hudon C., Cattaneo A. and Pinel-Alloul B., 1998. Periphyton as an indicator of water quality in the St Lawrence River (Québec, Canada). Environ. Pollut., 101, 13-24.

Wehr J.D., Stancheva R., Truhn K. and Sheath R.G., 2013. Discovery of the rare freshwater brown alga Pleurocladia lacustris (Ectocarpales, Phaeophyceae) in California streams. West $N$. Am. Naturalist, 73, 148-157.
Welch E.B., Jacoby J.M., Horner R.R. and Seeley M.R., 1988. Nuisance biomass levels of periphytic algae in streams. Hydrobiologia, 157, 161-168.

Whitton B.A., 1988. Hairs in eukaryotic algae. In: Round F.E. (ed.), Algae and the Aquatic Environment. Contributions in Honour of J.W.G. Lund. Biopress, Bristol, UK, 226-460.

Whitton B.A., 1991. Use of phosphatase assays with algae to assess phosphorus status of aquatic environments. In: Jeffrey D.W. and Madden B. (eds.), Bioindicators and Environmental Management. Academic Press, London, 295-310.

Whitton B.A. and Kelly M.G., 1995. Use of algae and other plants for monitoring rivers. Aust. J. Ecol., 20, 45-56.

Whitton B.A. and Mateo P., 2012. Rivulariaceae. In: Whitton B.A. (ed.), Ecology of Cyanobacteria II. Their Diversity in Space and Time. Springer, London, UK, 561-592.

Whitton B.A., 2012. Changing approaches to monitoring during the period of the Use of Algae for Monitoring Rivers symposia. Hydrobiologia, 695, 7-16.

Whitton B.A., 2013. Use of Benthic Algae and Bryophytes for Monitoring Rivers. J. Ecol. Environ., 36, 95-100.

Whitton B.A., Yelloly J.M., Christmas M. and Hernández I., 1998. Surface phosphatase activity of benthic algal communities in a stream with highly variable ambient phosphate concentrations. Verh. Int. Ver. Theoret. Angew. Limnol., 26, 967-972.

Whitton B.A., Clegg E., Christmas M., Gemmell J.J. and Robinson P.J., 2002. Development of Phosphastase Assay for Monitoring Nutrients in Rivers - Methodology Manual for Measurement of Phosphatase Activity in Mosses and Green Algae. Environment Agency of England and Wales STRE106-E-P.

Winterbourn M.J., 1990. Interactions among nutrients, algae and invertebrates in a New-Zealand mountain stream. Freshwater Biol., 23, 463-4.

Zelinka, M. and Marvan, P., 1961. Zur Präzisierung der biologischen Klassifikation der Reinheit fließender Gewässe. Arch. Hydrobiol., 57, 389-407. 